\title{
HYPOGENIC CAVES IN WESTERN UMBRIA (CENTRAL ITALY)
}

\section{HIPOGENE JAME V ZAHODNI UMBRIJI (OSREDNJA ITALIJA)}

\author{
Marco MENICHETTI ${ }^{1}$
}

\begin{abstract}
s
UDC 551.44(450.55)

Marco Menichetti: Hypogenic caves in western Umbria (central Italy)

Three karst areas located in the western sector of the Umbria Region (Central Italy) are here described: one north of Perugia, and the others to the south, close to Todi. All the end members of karst processes, from solution caves to Quaternary travertine deposits, are present in this region, associated with $\mathrm{CO}_{2}$ and $\mathrm{H}_{2} \mathrm{~S}$ emissions. The geological and hydrogeological aspects of the main karst systems are analyzed and their underground morphologies and patterns taken into account. Caves have different sizes and vary from a single conduit to complex systems, where the passages show features related to a possible hypogenic speleogenesis. In the area north of Perugia there are small horizontal and vertical solution caves developed in poorly karstified marly limestone, along fracture systems, where phreatic morphologies are prevalent. The endogenic $\mathrm{CO}_{2}$ emissions seem to drive the underground karst evolution. Pozzi della Piana, located west of the town of Todi, is a fossil branchform network cave system developed in a Quaternary travertine and extending for more than $2500 \mathrm{~m}$. The cave passages are arranged on at least two levels, with phreatic morphologies, cupola ceilings, and blind pits. Microcrystalline spalled gypsum blocks are associated with cusp features and wall pockets. The cave-forming process is believed to be linked to travertine deposition by supersaturated carbonate hydrothermal water rich in $\mathrm{H}_{2} \mathrm{~S}$. In the Parrano area, the underground karst system consists of solution caves extending for many hundreds of meters at different elevations in both sides of a small gorge. The cave patterns vary from single conduits to ramiform passages with anastomotic galleries and pits that intercept the water table with a temperature of $26^{\circ} \mathrm{C}, p \mathrm{CO}_{2}$ of $10^{-1} \mathrm{~atm}$, and $\mathrm{H}_{2} \mathrm{~S}$ concentrations of $10 \mathrm{mg} / \mathrm{l}$. Spongework, corrosion pockets, and cupola ceilings are common morphologies, with gypsum replacing limestone wall deposits. Cave formation by hypogenic speleo-
\end{abstract}

\author{
Izvleček UDK 551.44(450.55) \\ Marco Menichetti: Hipogene jame v zahodni Umbriji (osred- \\ nja Italija)
}

V članku opisujemo tri kraška območja v Umbriji (osrednja Italija) v bližini Perugie. Kraške oblike v jamah in debeli sloji kvartarnega lehnjaka pričajo o procesih povezanih $\mathrm{z}$ izhajanjem $\mathrm{CO}_{2}$ in $\mathrm{H}_{2} \mathrm{~S}$. Obravnavamo geološke in hidrogeološke značilnosti območja $\mathrm{v}$ povezavi $\mathrm{z}$ morfologijo in porazdelitvijo podzemnih rovov. Velikost in geometrija jamskih sistemov na območju je zelo spremenljiva, od enostavnih kanalov do kompleksnih sistemov, ki so verjetno rezultat hipogene speleogeneze. Na območju severno od Peruggie je več jam v slabo zakraselih lapornatih apnencih. Razvoj rovov je potekal pretežno $v$ freatičnih pogojih vzdolž razpok. Na razvoj teh jam je verjetno vplival dotok $\mathrm{CO}_{2}$ iz globin. Sistem Pozzi della Piana je razvit $\mathrm{v}$ kvartarnih lehnjakih zahodno od mesta Todi. Gre za $2500 \mathrm{~m}$ dolg sistem, katerega rovi so razviti vsaj v dveh etažah. V jami najdemo veliko stropnih kupol, slepih brezen in drugih freatičnih oblik. Razvoj jam je tu verjetno povezan z odlaganjem lehnjaka iz prenasičene vode bogate $\mathrm{s}_{2} \mathrm{~S}$. Na obmučju Parrana je več sto metrov dolg jamski splet, ki se razteza na različnih višinah na obeh straneh manjše soteske. Geometrija jamskih rovov je pestra, od enostavnih kanalov do razvejanih rovov, anastomoznih galerij in brezen, ki sekajo gladino podtalnice s temperaturo $26^{\circ} \mathrm{C}$, veliko kocentracijo $\mathrm{CO}_{2}$ $(0,1 \mathrm{~atm}) \mathrm{H}_{2} \mathrm{~S}(10 \mathrm{mg} / \mathrm{l})$. O hipogenem razvoju pričajo številne oblike (gobasti spleti, korozijske kotlice, stropne kupole) in plasti sadre, ki nadomeščajo raztopljen apnenec. Jamske oblike, ki kaejo na hipogeno speleogeneze najdemo v številnih jamah v Apeninih. V sistemu Monte Cucco in Frasasi so prisotne fosilne in aktivne hipogene oblike, ki so v drugačnem kontekstu nastale s podobnimi procesi.

Ključne besede: speleogeneza, hipogene jame, $\mathrm{H}_{2} \mathrm{~S}, \mathrm{CO}_{2}$, Italija.

\footnotetext{
${ }^{1}$ Dipartimento di Scienze della Terra, della Vita e dell’Ambiente-Università di Urbino, Italia, e-mail: marco.menichetti@uniurb.it

Received/Prejeto: 9.9.2010
} 
genesis is also well known in the Apennine karst system of M. Cucco and Frasassi, where both fossil and active processes are observable. The same processes are responsible for the genesis of these karst systems in different geological and hydrogeological contexts.

Keywords: speleogenesis, hypogenic caves, $\mathrm{H}_{2} \mathrm{~S}, \mathrm{CO}_{2}$, Italy.

\section{INTRODUCTION}

In Central Italy all the end-members of karst processes can be found, from solution caves to carbonate travertine deposits (Fig. 1). Moreover, the main cave-forming processes are related to deep-seated hydrogeological recharge where limestone corrosion is driven by endogenic agents (Menichetti 2009). The region contains abundant Quaternary travertine deposits and is rich in volcanic, crustal and mantle-derived $\mathrm{CO}_{2}$ and $\mathrm{H}_{2} \mathrm{~S}$ emissions (Fig. 1).
Through more than one century of speleological research, many limestone caves have been identified. These caves are characterized by a variety of patterns and morphology sizes including three-dimensional maze systems and deep shafts, with both endogenic $\mathrm{CO}_{2}$ vents and active sulfuric streams. Although sulfuric acid-related speleogenesis typically produces gypsum deposits, in caves where the karstification processes are driven by subter-

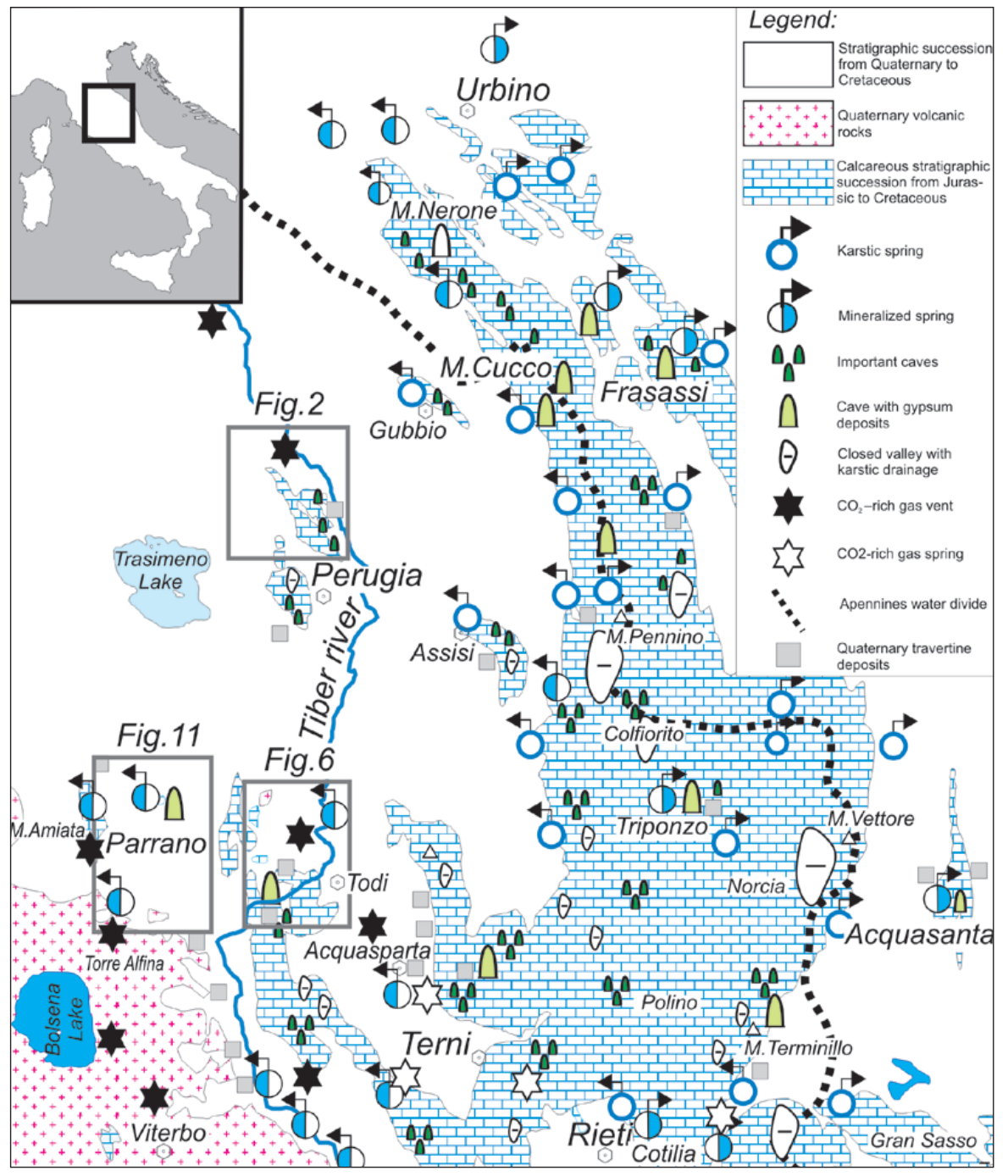

Fig. 1: Map of the main karst features of Central Italy. The insert frames indicate the figures with geological maps. 
ranean $\mathrm{CO}_{2}$ sources voids and speleothems are the only final products.

Studying these caves permits us to expand our understanding of the different aspects of underground karst, and Central Italy is one of the world's best locations to observe both active and fossil hypogenic speleogenesis processes in different geological contexts. In the Umbria-Marche Apennine region, the presence of important hypogenic caves has been well documented since several decades of research and exploration of the vertical system of M.Cucco and Faggeto Tondo and the maze systems of the still active Frasassi and Acquasanta caves. A general description of the different morphological aspects of these karst systems permits the identification of the primary speleogenetic processes (Galdenzi \& Menichetti 1989, 1995; Galdenzi 2009) of these systems within a geological and hydrogeochemical framework (Menichetti 2009).

The geological characterization of hypogenic cave development needs to consider the great variety and unusual characteristics of Central Italy's underground landscape. Even though the general speleogenetic reactions are known, the precise geological, hydrogeological and geochemical conditions of their occurrence need to be documented, in particular the role of gases $\left(\mathrm{H}_{2} \mathrm{~S}\right.$, $\mathrm{CO}_{2}$ ) and their association with other mineral species. Hydrogeology and, especially, hydrochemistry are key in understanding the space/time evolution of these hypogenetic karst systems.
After a decade there has been renewed interest in hypogenic cave speleogenesis studies using different approaches that explore the roles of both deep-seated hydrogeological recharge (sensu Klimchouk 2007) and the presence of endogenically driven limestone corrosion (sensu Palmer 2007) have been conducted. Hypogenic caves are well known in Europe and different parts of the world, from Central Asia to North and South America, and especially the underground fossil systems in the Guadalupe Mountains in New Mexico and Texas (Hill 1987; DuChene et al. 2000).

In this paper we will present a description of the underground morphologies and patterns of the main karst systems of western Umbria and place it within a geologi$\mathrm{cal}$ and the hydrogeological context. These caves vary in size, ranging from single conduit to complex systems, and their passages display features that can be related to hypogenic speleogenesis. The geochemistry of the groundwater and gas emission present in these karstic areas is taken into account for understanding their role in speleogenesis and better to characterize the factors that control hypogenic dissolution during cave development. The approach to understanding the role of hypogenic processes in the cave formation is here related to the geochemistry of rising aggressive fluids with respect to the hydrogeological conditions that drive the flow of water recharge to the cave-forming zone.

\section{GEOLOGICAL OUTLINES OF WESTERN UMBRIA}

The geology of Central Italy has been shaped predominantly by the continental Cenozoic collision of the Corsica/Sardinia and the now subducted Adriatic plates. Geological and geophysical data highlight two main sectors within this region: a western, Tyrrhenian sector dominated by Neogene-Quaternary, active, back-arc extensional tectonics and an eastern Adriatic sector dominated by an active compressional stress field (Cavazza \& Wezel 2003). The karstic carbonate Apennine foldthrust belt is within a transitional area between these two domains (Fig. 1).

The Tuscan-Umbro-Marchean sedimentary cover hosting the caves is part of the Meso-Cenozoic basin and consists of three main lithological units. The lower unit is about $1 \mathrm{~km}$ thick and is dominated by Upper Triassic dolomites and anhydrites unconformably overlying Paleozoic phyllitic basement rocks. The intermediate sequence of limestone and pelagic cherty-marly-carbon- ates is about $2500 \mathrm{~m}$ thick and spans from the Jurassic to the Paleocene. The upper unit comprises Neogene turbidite foredeep sediments about $3000 \mathrm{~m}$ thick. In western Tuscany and, especially, in the Apuan Alps, the carbonate succession underwent metamorphosed greenschist facies and represents the deep roots of the collisional orogen (Cavazza \& Wezel 2003). The area surrounding Rome has been active since the mid-Pleistocene ( 700 ka) and has remained intermittently active up to recent times resulting in the extrusion of K-undersaturated volcanics in association with some carbonatite magmas in several localities within the Apennine chain (Peccerillo 2005).

On the Tyrrhenian side of the Apennine belt, the results of the Neogene-Quaternary back-arc extension include a reduced thickness of the lithosphere, a system of NW-SE striking normal faults and associated basins, and high heat flow, producing in the areas many $\mathrm{H}_{2} \mathrm{~S}$ and 
$\mathrm{CO}_{2}$-rich hydrothermal vents (Minissale 2004). On the Adriatic side of the Apennine mud volcanoes, salt springs and $\mathrm{CH}_{4}$ emissions are well documented in hydrocarbon exploration data (Conti et al. 2000). In western Umbria, the high heat flow is estimated at $80 \mathrm{~mW} / \mathrm{m}^{2}$, increasing westward to more than $200 \mathrm{~mW} / \mathrm{m}^{2}$ in the M. Amiata area (Della Vedova et al. 2001).

The largest caves in the area are located in a $1000 \mathrm{~m}$ thick Jurassic carbonate bank, where syngenetic porosity in sedimentary facies of packstone and grainstone is well developed. Occasionally, small caves are hosted in Cenozoic marly-limestone successions confined by sandstone and marl formations (Menichetti 1987). Quaternary travertine deposits are scattered throughout the region, particularly in Tuscany and Latium. However, caves as- sociated with both thermal and cold springs are only in a few localities in the Apennine chain (Minissale 2004) (Fig. 1).

The main phase of the Apennine chain uplift, relevant to cave development, took place within the Pleistocene (Mayer et al. 2003). The primary tectonic features controlling the underground Apennine karst morphology and the carbonate reservoir groundwater drainages are a system of N-S transpressive faults and networks of conjugated joint sets distributed in primary NE-SW and secondary NW-SE directions. Specifically, the N-S faults are associated with the main passages and rooms, and control the development of the larger underground voids, while solutional morphologies are associated with joint systems (Menichetti 1987; Mayer et al. 2003).

\section{NORTH OF PERUGIA AREA}

\section{GEOLOGY}

The landscape north of Perugia is characterized by uneven morphologies with limestone and marl outcrops in the mountain range at 1000 to $200 \mathrm{~m}$ asl. The whole area has been intensely impacted by human activity from the time of the Etruscan civilization (VIII ${ }^{\circ}$ Century B.P.) by intensive agricultural activity, while the mountain slopes are covered by mesophile forests.

The geology north of the Perugia region is characterized by the presence of thick Neogene marls and sandstones from which emerge small karst limestone outcrops in two sets of $\mathrm{NE}$ verging rootless anticlines: the M. Acuto - M. Tezio to the west and M. MussarelloM. Murlo to the east (Fig. 2). The Neogene tectonic compression structures are dissected by a set of en echelon normal fault systems with an offset of hundreds to thousands of meters. The fault planes are generally SW dipping but there are a few low angle NE dipping faults that place the Neogene terrigenous formations in direct contact and over Triassic anhydrites (Minelli \& Menichetti 1990; Brozzetti 1995; Menichetti 2003).

The primary karst lithologies consist of CretaceousPaleogene pelagic limestone and marly-limestone in layers tens of meters thick, with a few small caves occurring in the Jurassic and Upper Triassic limestone (Menichetti 2003). The surface karst morphologies are represented by a few localized dolines and depressions particularly in the M. Tezio area (Dessau 1956).

On the western bank of the Tiber river, the dendritic hydrographic network drains toward the NE with an average base flow of $15 \mathrm{l} / \mathrm{sec} / \mathrm{km}^{2}$ (Boni et al. 1988). The main aquifers are located in the Ceno-Mesozoic limestone, with a relatively low specific discharge of $10 \mathrm{l} / \mathrm{sec} / \mathrm{km}^{2}$ due mainly to the small extent of the infiltration area. The large extent of the flysch sediments represents the main aquiclude which controls the drainage network and the location of the main sink points at the boundary with the limestone outcrops. In the Pian del Nese area, several sinkholes drain the small closed plain (Viviani \& Passeri 1965). The springs in the area have a discharge of a few $1 / \mathrm{sec}$ with groundwater compositions ranging from $\mathrm{Ca}-\mathrm{SO}_{4}$ to $\mathrm{Ca}(\mathrm{Mg})-\mathrm{HCO}_{3}, \mathrm{pCO}_{2}$ varying between $10^{-2}$ and $10^{-0.05} \mathrm{~atm}$ and $\mathrm{H}_{2} \mathrm{~S}$ content reaching up to $5 \mathrm{mg} / \mathrm{l}$ (Chiodini et al. 1999).

Located along the Tiber valley, at the junction with the T. Nese, there is a travertine outcrop topped by the medieval castle of Ascagnano. At an altitude of $280 \mathrm{~m}$ asl and a few tens of meters above the thalweg, this outcrop is a few hundred square meters in size, with a thickness of about $10 \mathrm{~m}$. The original extent may have been larger and was subsequently reduced by weathering and fluvial erosion. The travertine overlies Pleistocene fluvial sediments deposited by the Tiber and having lithologies that display high porosity, significant organic matter content, and a very low cohesion. The sediments have a $\delta^{13} \mathrm{C}$ of - 3.5 (\% PDB) and a $\delta^{18} \mathrm{O}$ of 25.63 (\% SMOW) with a Sr content of $584 \mathrm{mg} / \mathrm{kg}$ (Minissale et al. 2002).

The area is characterized by the presence of several $\mathrm{CO}_{2}$ vents, the largest of which is located a few kilometers west of Umbertide, along a slope a few tens of meters above the western bank of the Tiber valley (Fig. 2). The gas vent is located in the Neogene sandstone and marls in proximity of a regional thrust fault. The cold vent $\left(\right.$ about $13^{\circ} \mathrm{C}$ ) consists of a vigorous roiling pool of 


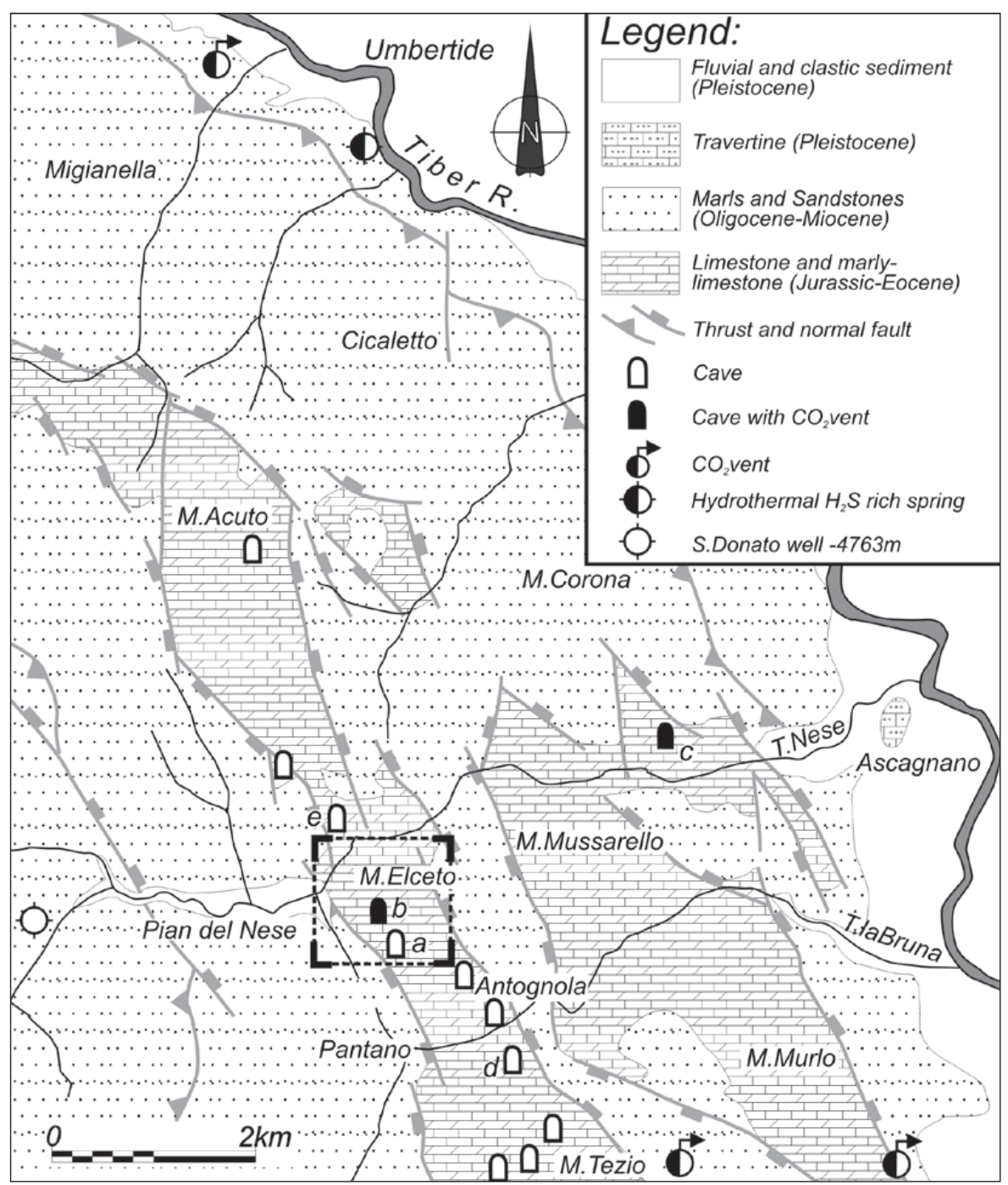

Fig. 2: Geological map of the M. Acuto and M. Tezio areas showing the locations of the main karstic features (geology after Compagnoni et al. 1981). Caves described in the text: a) Abisso I di Montecelli; b) Abisso II di Monticelli; c) Buca del Serpente; d) Pozzo dei Piantoni; e) Buca della Scanata. Location of the map in Fig. 1. The insert frame shows the location of Fig. 3.

muddy water at the bottom of an elongated depression of about $5 \mathrm{~m}$ in depth and $20 \mathrm{~m}$ in diameter (Fig. 5a). The estimated discharge of gas is about $3 \mathrm{~m}^{3} / \mathrm{sec}$ with a composition of $93 \% \mathrm{CO}_{2}, 6 \% \mathrm{~N}_{2}$ and $0.25 \% \mathrm{CH}_{4}$ (Rogie et al. 2000; Italiano et al. 2004). An oil exploration well (4763 m deep) drilled a few $\mathrm{km}$ west of Pian del Nese (Fig. 2) through a few hundred meters of Neogene marls and sandstones reached the Triassic anhydrites. The bottom hole fluid pressure was found to be $96 \mathrm{MPa}$, corresponding to about $85 \%$ of lithostatic load with a gas composition of $99 \% \mathrm{CO}_{2}$ (Chiodini et al. 1999). This scenario is completed by the existence of many other dry vents and degassing areas, closer to the karst limestone outcrops north of Perugia, in the M. Tezio area (Fig. 2).

\section{CAVES}

A few of the scattered caves distributed in this area are in Cretaceous limestone of the M. Tezio - M. Elceto hill. The caves are generally small, with single passages of a few tens of meters in length, located in correspondence with the main tectonic lineaments (Fig. 2). North of the Pian del Nese area, small decametric caves present morphologies with single circular conduits, cupolas, and other phreatic features (Viviani \& Passeri 1965).

The most important of these caves are the Abisso Monticelli $\mathrm{II}^{\circ}$ and Buca del Serpente (Fig. 2a \& c, respectively), which have high $\mathrm{CO}_{2}$ concentrations in the underground air. Both caves have been known and explored since the middle of last century (Lippi Boncambi 1941; Dessau 1956).

The Abisso Monticelli cave is a vertical shaft that opened in the SW slope of M. Elceto during a strong storm in 1961 (Passeri 1963). The entrance is a depression a few meters wide, located in proximity to a small stream and an outcrop of slope debris a few meters thick. The cave is located in sub-horizontal strata of Paleocene-Eocene marls and limestone, in a block delimited by a system of NW-SE normal faults and N-S strike-slip 

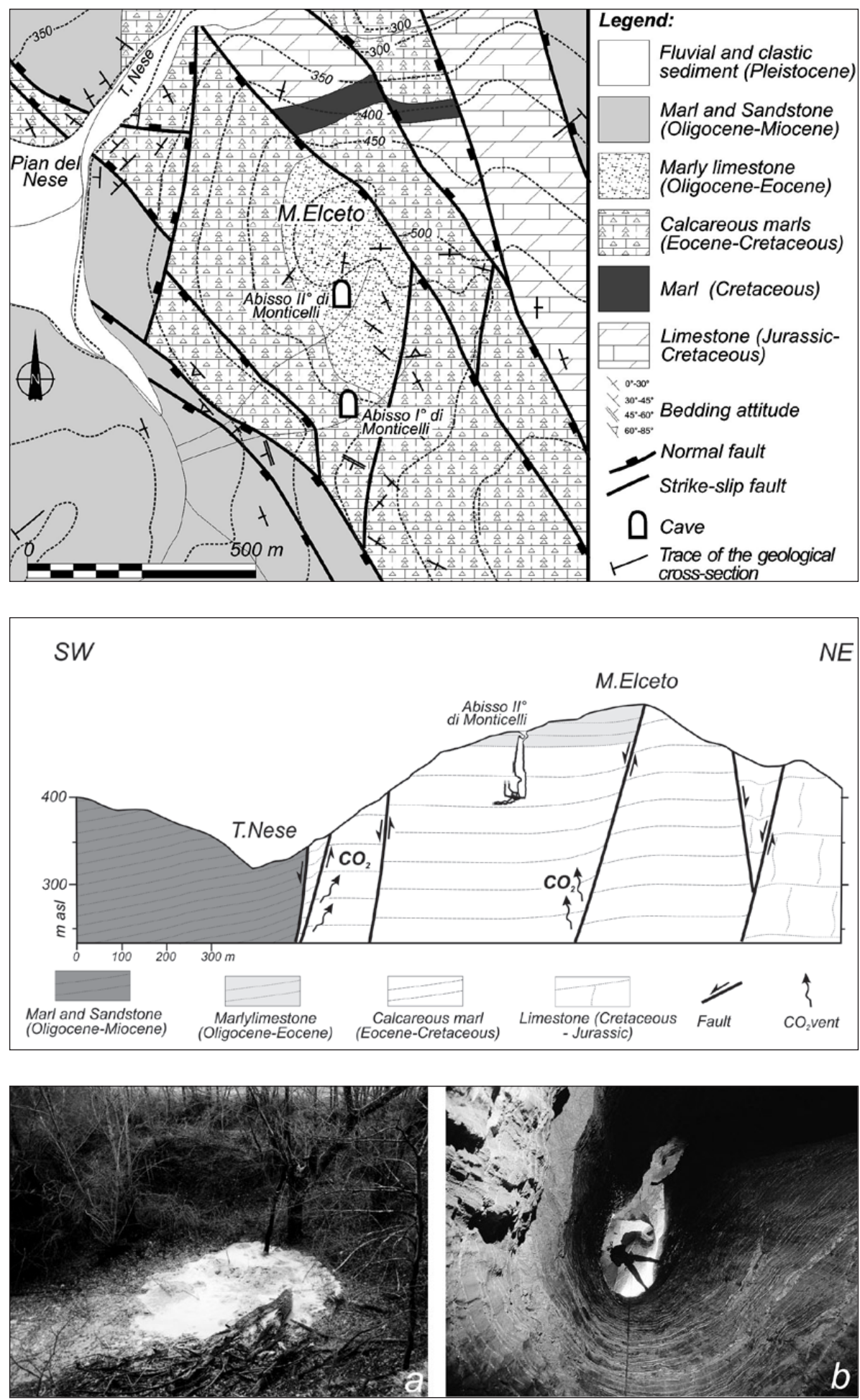

Fig. 3: Geological Map of Pian del Nese - Monticelli area. Location in Fig. 2.

Fig. 4: Geological cross-section of $M$. Elceto with the location of Abisso II di Monticelli and the possible origin of $\mathrm{CO}_{2}$ indicated. Trace of the section is in Fig. 3. Note that the horizontal and vertical scales are different.

Fig. 5: a) $\mathrm{CO}_{2}$ vent close to Umbertide; the pool is about $3 \mathrm{~m}$ wide; b) Abisso $I I^{\circ}$ Monticelli shaft. faults (Fig. 3). The main fractures are represented by a system of NW-SE and N-S joints. The cave entrance is a narrow passage, in weathered marls, the top of a single sub-vertical and circular shaped shaft $10 \mathrm{~m}$ in diameter and $78 \mathrm{~m}$ in depth, known as Pozzo Dessau (Fig. 4). The cave developed in $30 \mathrm{~m}$ of Paleocene-Upper Cretaceous limestone beds. At the base, the pit is connected with a blind chimney of similar shape and with a N-S oriented gallery composed of a narrow subvertical passage with several steps of a few meters containing a seasonal 
stream with discharge of several 1/sec (Fig. 4). The cave ends in an impassable narrow passage where $\mathrm{CO}_{2}$ concentrations close to $10 \%$ have been detected, representing a serious hazard for further speleological exploration. The underground morphologies are characterized by a contrast of the large shaft and the small fissure passage at the cave end. In the lower section of the shaft, phreatic morphologies as well as vadose corrosion forms are well developed (Fig. 5b). The cave's origin in this poorly karstified lithology seems to be connected to the high concentration of endogenic $\mathrm{CO}_{2}$.
The Buca del Serpente is a small, single passage cave, a few meters wide and many meters long, in Cretaceous cherty limestone of the northern slope of the $\mathrm{T}$. Nese valley (Fig. 2c) (Lippi Boncambi 1941). The cave is characterized by the presence of seasonal air flow with $\mathrm{CO}_{2}$ concentrations of 1 to $5 \%$. The cave is located in proximity to a N-S fault with a large shear zone, which most likely represents the primary conduit for the endogenic gas flow.

\section{TODI AREA}

\section{GEOLOGY}

Southwestern Umbria, around Todi, is a hilly terrain with a mean altitude of $400 \mathrm{~m}$, dotted with small villages and a prevalent cover of deciduous mixed mesophile forests. The geological landscape is characterized by Oligo-Miocene marls and turbidite sandstone outcrops. PlioPleistocene continental sediments with fluvial and marsh facies are present along the Tiber valley at different altitudes above the thalweg (Fig. 6).

Outcrops of Cretaceous limestone and calcareousmarls occur in association with a rootless NE verging anticline of M. Piatto - Civitella del Lago (Fig. 6) dissected by several N-S right-lateral strike-slip faults related to thrust emplacement. These Neogene compression structures are cross-cut by a set of NW-SE striking Plio-Pleistocene normal faults with an offset that can reach many hundreds of meters (Fig. 7).

In the vicinity of the town of San Venanzo (Fig. 6), there is a small volcanic center characterized by olivine melilitite lavas and dykes associated with carbonate-rich (about 10 wt \%) pyroclastic rocks with an ${ }^{40} \mathrm{Ar} /{ }^{39} \mathrm{Ar}$ age of $265 \mathrm{ka}$ (Laurenzi et al. 1994). In the M. Piatto area (Fig. 6) and close to Acquasparta (Fig. 1) there are small outcrops of phreatomagmatic deposits of ashes and lapilli with a kamafugitic affinity and an ${ }^{40} \mathrm{Ar} /{ }^{39} \mathrm{Ar}$ age of $390 \mathrm{ka}$. They are believed to have been erupted from monogenetic centers aligned along a N-S fault (Peccerillo 2005).

The hydrographic network is well developed with a dendritic pattern in marls and sandstones, with a regional drainage toward the Tiber River. In the carbonate outcrops close to Titignano, several sinkholes drain the superficial streams with resurgences located along the Tiber valley. The main aquifers are located in the Ceno-Mesozoic limestone, with a specific discharge of $15 \mathrm{l} / \mathrm{sec} / \mathrm{km}^{2}$.
There are gas vents and sulfuric springs in the western bank of the Tiber valley in the Monte Castello di Vibio area (Fig. 6). The main emission is located in the Miocene marls in a few meter wide depression on the hill slope, where a bubbling pool of muddy water releases a cold $\left(14^{\circ} \mathrm{C}\right)$ gas flux of about $1 \mathrm{~m}^{3} / \mathrm{sec}$, where $\mathrm{CO}_{2}$ represents $92 \%$ of the gas (Italiano et al. 2004). The southernmost natural sparkling water springs that are partially utilized for industrial purposes are located close to Acquasparta (Fig. 1). These carbonate/sulfuric water springs have a $p \mathrm{CO}_{2}$ in the range from 0.08 to $0.006 \mathrm{~atm}$ and $\mathrm{H}_{2} \mathrm{~S}$ content of $3 \mathrm{mg} / \mathrm{l}$ (Chiodini et al. 1999).

Quaternary travertine outcrops of different size and thickness have been noted on both sides of the Tiber Valley at two altimetric levels. The northernmost outcrop, near Titignano Castel, is at an altitude of $490 \mathrm{~m}$ and has an area of about $1 \mathrm{~km}^{2}$ with a thickness of about 50 meters (Fig. 6). Further south at the same altitude, around Civitella del Lago, there are two smaller travertine outcrops of about $0.5 \mathrm{~km}^{2}$ with a thickness of a few tens of meters. Both outcrops overlie Upper Pliocene (1.6 Ma) continental yellow sands and blue clay.

The lowermost travertine bank, hosting the Pozzi della Piana cave, is east of Roccaccia at an altitude of 190 $\mathrm{m}$, with an area of about $0.5 \mathrm{~km}^{2}$, and an average thickness of $100 \mathrm{~m}$. It discordantly overlies Upper Cretaceous limestone with a contact characterized by a hydrothermally altered cataclastic shear zone related to a subvertical N-S fault.

The origin of these fossil travertines is also believed to be thermogenic (Passeri 1973) when spatially unassociated with thermal water. In the Lazio and Tuscany regions, thermal springs and $\mathrm{CO}_{2}$ vents associated with travertine deposits are very common (Fig. 1). In the Rome area, travertine deposition started just after or 


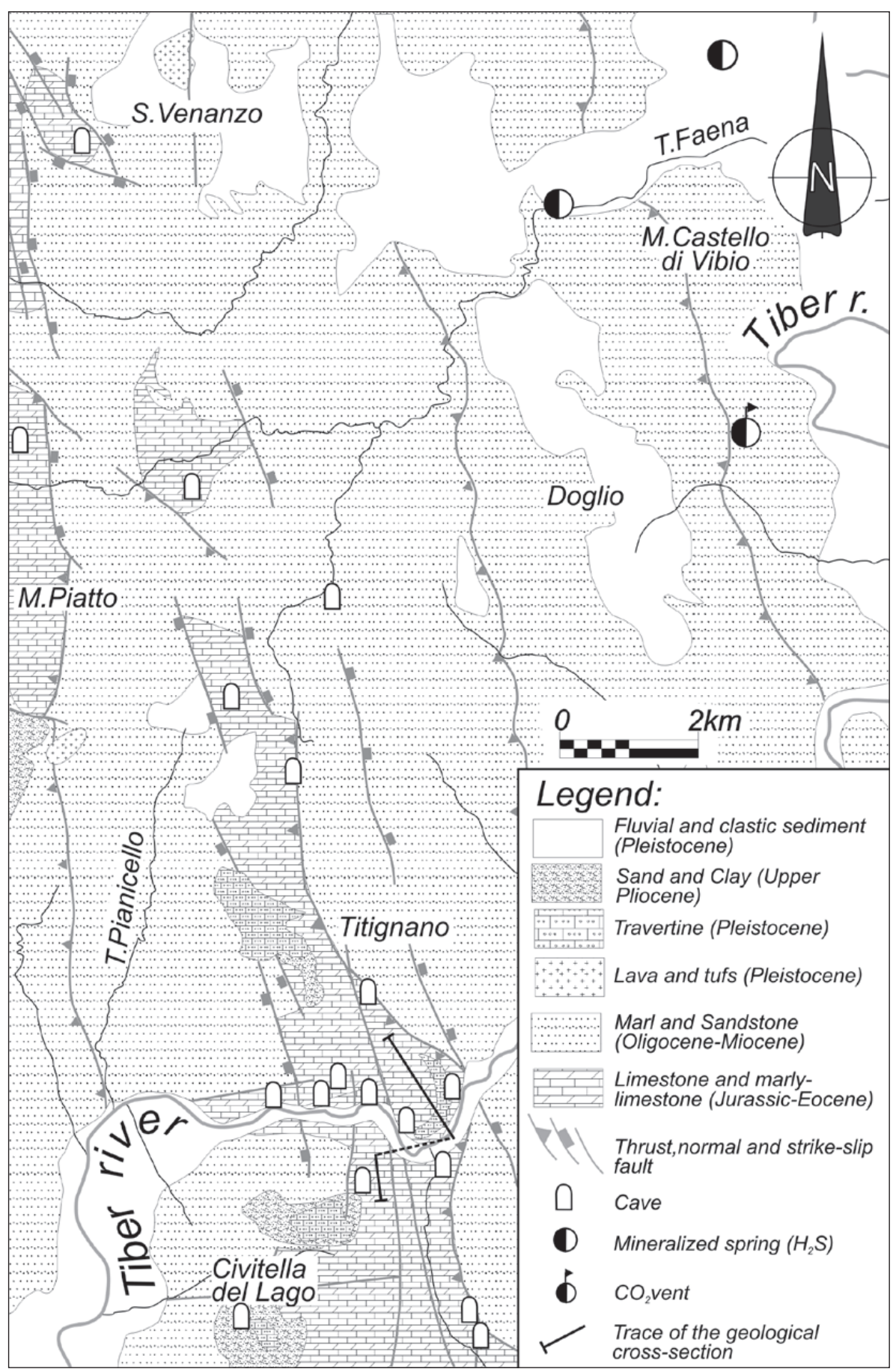

Fig. 6: Geological map of Titignano - Pozzi della Piana area (after Compagnoni et al. 1981). Location in Fig. 1.

concurrent with the last phase of volcanic activity in the late Pleistocene (Minissale 2004).

The Pozzi della Piana develops in a massive travertine with low organic content and a well developed moldic and shelter porosity. The Titignano travertine is composed of a sequence of benches separated by erosional surfaces gently dipping south, with a thickness of many meters. The geometry and the attitude of the deposit show that the travertine grew in a southward aggradational fashion in lenticular mound/ridge type deposits (sensu Pentecost 2005). Calcite is the most common carbonate phase within travertine with a significant content of $\mathrm{Sr}$ (about $1500 \mathrm{mg} / \mathrm{kg}$ ) related to the thermal water rising through the Triassic anhydrites. The superficial karst in the travertine is well developed and contains several large depressions and dolines of a few hundred meters in 


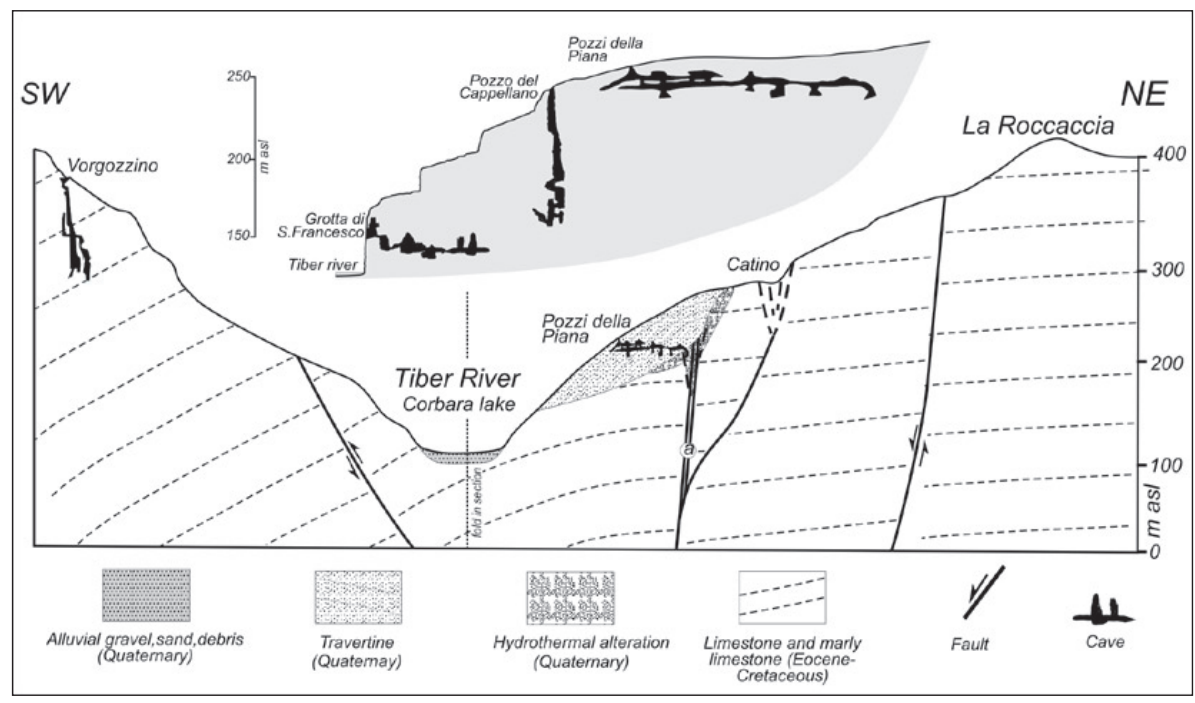

Fig. 7: Geological cross-section of the Pozzi della Piana area. The possible hydrothermal conduits for travertine deposition are indicated (a). In the upper part, schematic altimetric relationships between the karst systems are shown. The crosssection trace is shown in Fig. 6. Note that horizontal and vertical scales are different and the cross-section fold corresponds to the Tiber River.

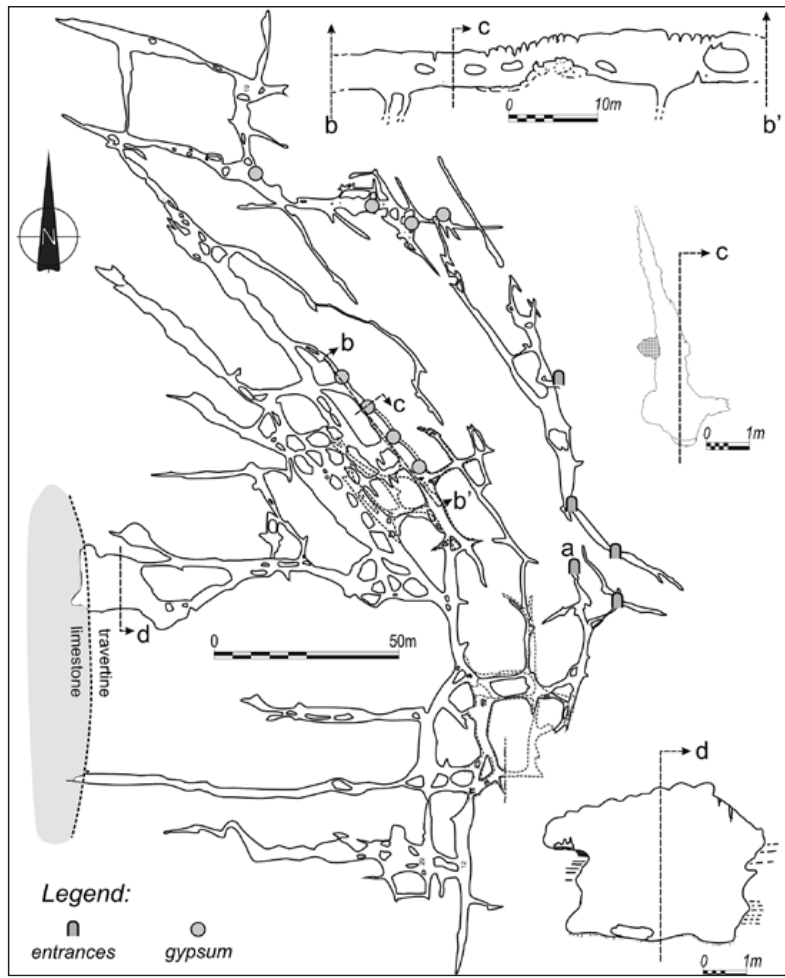

Fig. 8: Map of the Pozzi della Piana cave with transversal and longitudinal sections. The boundary between travertine and Upper Cretaceous limestone is indicated. Entrance pit (a), Galleria Gotica (b) and Sala dei Vortici (d). From: www.cens.it - used with permission.

diameter (Passeri 1973). In the bare rock outcrops small karren are observable.

Underground karst can be found in both the Roccaccia travertine bank, where Pozzi della Piana has developed over about $2500 \mathrm{~m}$ of hypogenic branchform, solutional galleries, and in Upper Cretaceous limestone with deep shafts and small solution passages located in correspondence with different Tiber river terraces (Fig. 7).

\section{CAVES}

The Pozzi della Piana cave and the surrounding area, which is also known for an archeological site of Neogene age (Passeri 1967), developed as a system of fossil solution maze, fissure, and network passages, arranged in at least two levels. The prevalent morphology is a network of single passages, with primary horizontal galleries at $15 \mathrm{~m}$, connected to a smaller, shallower level a few meters below the surface where the entrances are located (Fig. 8). Several ascending ellipsoidal shape conduits connect the main level to the deepest passages at $-25 \mathrm{~m}$ (Passeri 1973). The cave developed in the travertine bank, but only in its western branch, in the wall of the Sala dei Vortici (Fig. 8, point d), is the altered contact with the Upper Cretaceous limestone observable (Fig. 9b). Here, in the floor, a few blind pits a few meters deep and partially filled with clay sediments could represent the original ascending hydrothermal conduits. In the same branch partially eroded and weathered stalagmites are present (Fig. 9b).

With respect to the entrance (Fig. 8, point a), the northern part of the cave is arranged in a system of longitudinal NW-SE oriented galleries. In the central part, a maze system of anastomotic passages interconnects the main corridors. This preferential direction is related to a system of joints associated with the main extensional faults. In the southern branch, the main passages are developed along an E-W direction and linked with a N-S oriented maze system. Here, several collapsed blocks associated with an E-W left-lateral strike-slip fault control the morphology of this part of the cave.

The single passages are a few meters in size and have triangular shape morphology with planar pave- 

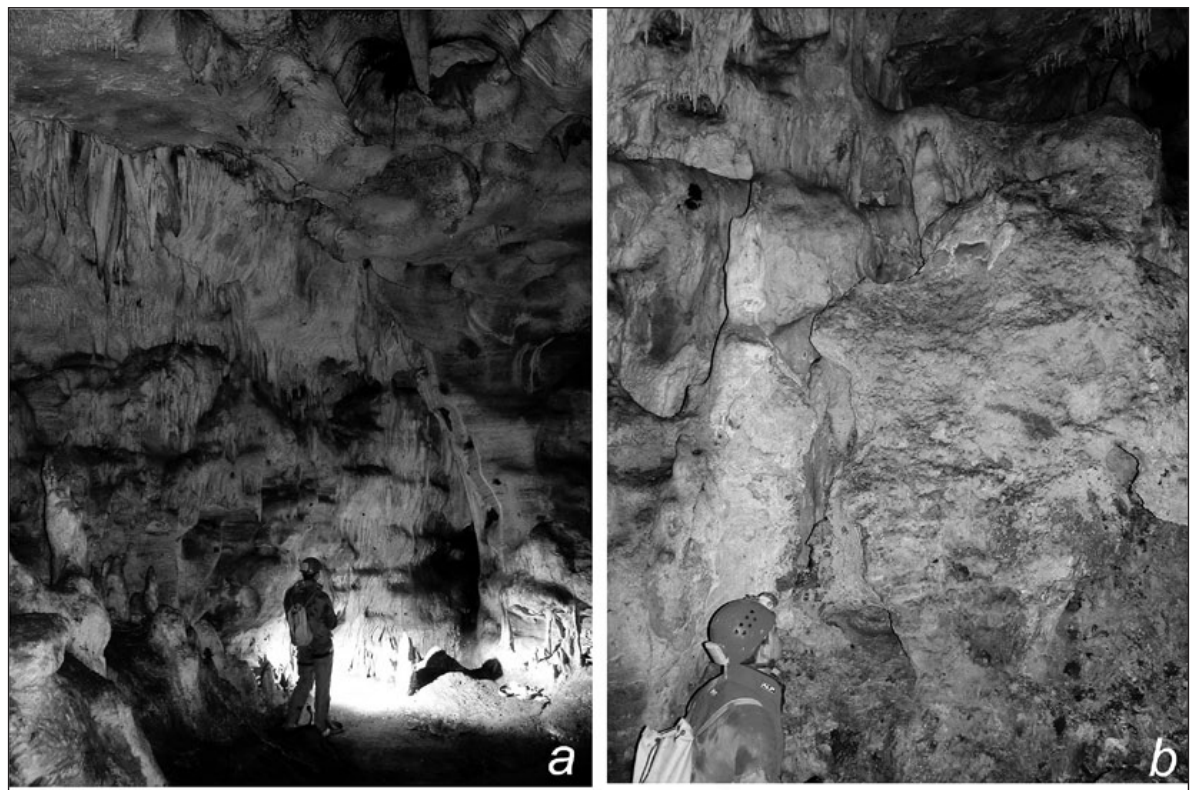

Fig. 9: Pozzi della Piana - a) Sala dei Vortici morphologies; b) Sala dei vortici - alteration crust at the boundary between Travertine and Upper Cretaceous limestone; c) Galleria Colonna travertine spongework morphologies; d) Galleria Gotica with gypsum deposits in the large pocketed wall.
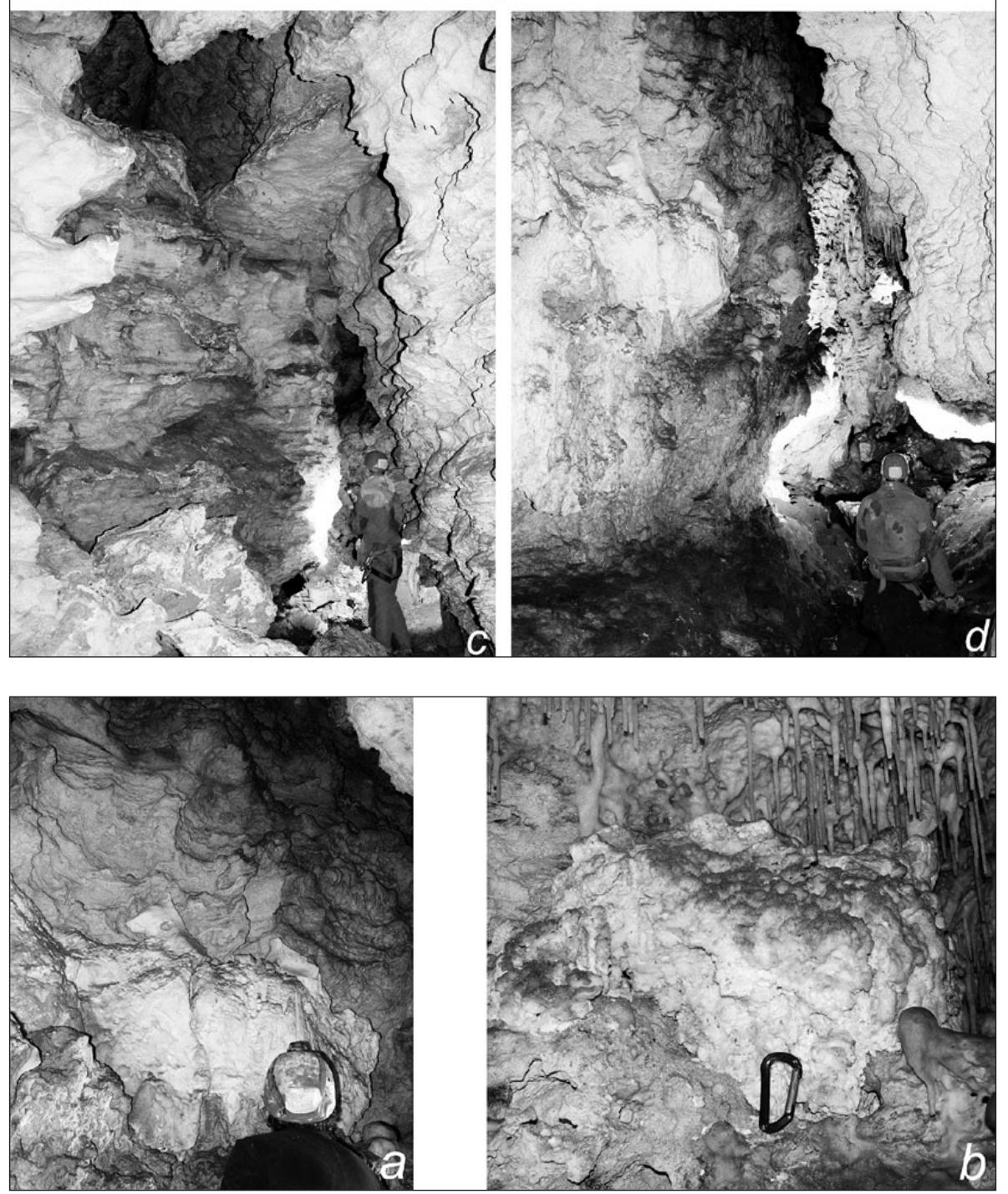

Fig. 10: Pozzi della Piana primary gypsum microcrystalline deposits. a) morphologies in correspondence of gypsum deposits; b) gypsum associated with carbonate speleothems. 
ments and irregular walls with notches, solution pockets and spongework (Fig. 9c). Blind pits as well as chimney shafts ascending toward the surface are scattered along the main passages. The anastomotic voids correspond to the main drainage points located in travertine with the highest porosity (Fig. 9c). Convection cupola morphologies from decimetric to metric size are present, especially in Galleria Gotica and in the ceiling of Sala dei Vortici (Fig. 8, point b and d-Fig. 9d).

Wall morphologies are characterized by rounded and elongated bulges resulting from differential solution of the travertine levels. These cusp features, found in a few of the passages, contain microcrystalline gypsum (Fig. 10a). The pockets are centimeter-sized and located at the gypsum/bedrock interface. The gypsum rinds and blocks hang on the walls and have volumes varying from cubic decimeters to cubic meters. The primary gypsum is white and microcrystalline, with a thin brown alteration crust at the rock interface, while the recrystallized selenite crystals are present at the base of the main deposits. Various types of wall residues are present in different parts of the cave; however, they are mainly clay-rich and possibly related to the condensation/corrosion weathering processes. Carbonate flow and dripstones as well as both stalagmites and stalactites can be found in all the passages, while the presence of large columns is evidence of an important phase of carbonate deposition.

Boulders on the floor, travertine tilted blocks and breakdown deposits are especially common in the central part of the cave in association with a tectonized E-W lineament. A comparison of the cave passage altitudes and the terraces along the Tiber valley/Lago di Corbara (Fig. 7), aside from a few apparent correlations, paints a general picture that does not take into account differential uplift rates and needs to be investigated in more detail.

The presence of phreatic as well as vadose morphologies associated with gypsum deposits indicates a highly probable hypogenic origin of the Pozzi della Piana cave. Several unresolved questions remain, in particular the age of the travertine and speleothems. Moreover, the temporal relationship between cave deposits suggests that the corrosion sculptures pre-date gypsum deposits and carbonate speleothems (Fig. 10b). The known ages of the travertine outcrops in the area range between 60 and $300 \mathrm{ka}$ and correspond to the latest volcanic activity in the San Venanzo area. However, the temporal relationship between the travertine deposits and cave formation is ambiguous. On one hand, the travertine is the host rock for the cave, but its deposition could be contemporary with the emerging calcite supersaturated hydrothermal water. In addition, the presence of gypsum deposits suggests the participation of sulfuric acid in the carbonate dissolution. Possible development of travertine-hosted caves concurrently with the emergence of sulfur-rich hydrothermal springs is common in different geological contexts (Van Everdigen et al. 1985; Erol 1993; Pentecost \& Tortora 1989; Pentecost 2005; Menichetti 2008). In several cases, the caves represent the conduits for hydrothermal groundwater flow that fed the springs during travertine deposition.

\section{PARRANO AREA}

\section{GEOLOGY}

The hilly area of Parrano is located between the ridges of M. Peglia-M. Piatto (900 m asl) to the east and M. Cetona (1148 m asl) to the west, on the border with the Tuscany region (Fig. 1). The mean altitude is $400 \mathrm{~m}$, with prevalent deciduous mixed mesophile forests. The valleys are located at an altitude of $200 \mathrm{~m}$ and contain agricultural lands and several towns. The geology of the area is characterized by Pliocene post-orogenic continental sediments that uncomformably overlie marine Miocene turbidite sandstones and marls. Isolated Jurassic-Eocene karst limestone anticlines emerge in the Parrano Gorge and in the M. Cetona area (Fig. 11). Sets of NW-SE striking normal faults with offsets that reach thousands of meters dissect the Neogene compression structures (Piscopo et al. 2009).
The southernmost outcrops, around the town of Orvieto, consist of Quaternary volcanic rocks dominated by pyroclastic flow deposits and ignimbrites with minor lava flows of trachybasalt to trachyte and leucitite-leucite tephrite to phonolite compositions related to the Roman Magmatic province of the Vulsini district (age 0.6 to $0.15 \mathrm{Ma}$ ) (Peccerillo 2005). The magmatic necks of $\mathrm{M}$. Amiata (0.3-0.2 Ma) and Torre Alfina (0.82 Ma) are located a few kilometers to the west (Fig. 1).

The hydrographic network in the area is dendritic with drainage toward the Paglia river at an average base flow of $12 \mathrm{l} / \mathrm{sec} / \mathrm{km}^{2}$ (Chiodini et al. 1982). The main aquifers are located in the Ceno-Mesozoic limestone, with an average specific discharge of $10 \mathrm{l} / \mathrm{sec} / \mathrm{km}^{2}$.

The karst system is developed in Upper Cretaceous siliceous-calcareous marl that underlies very 


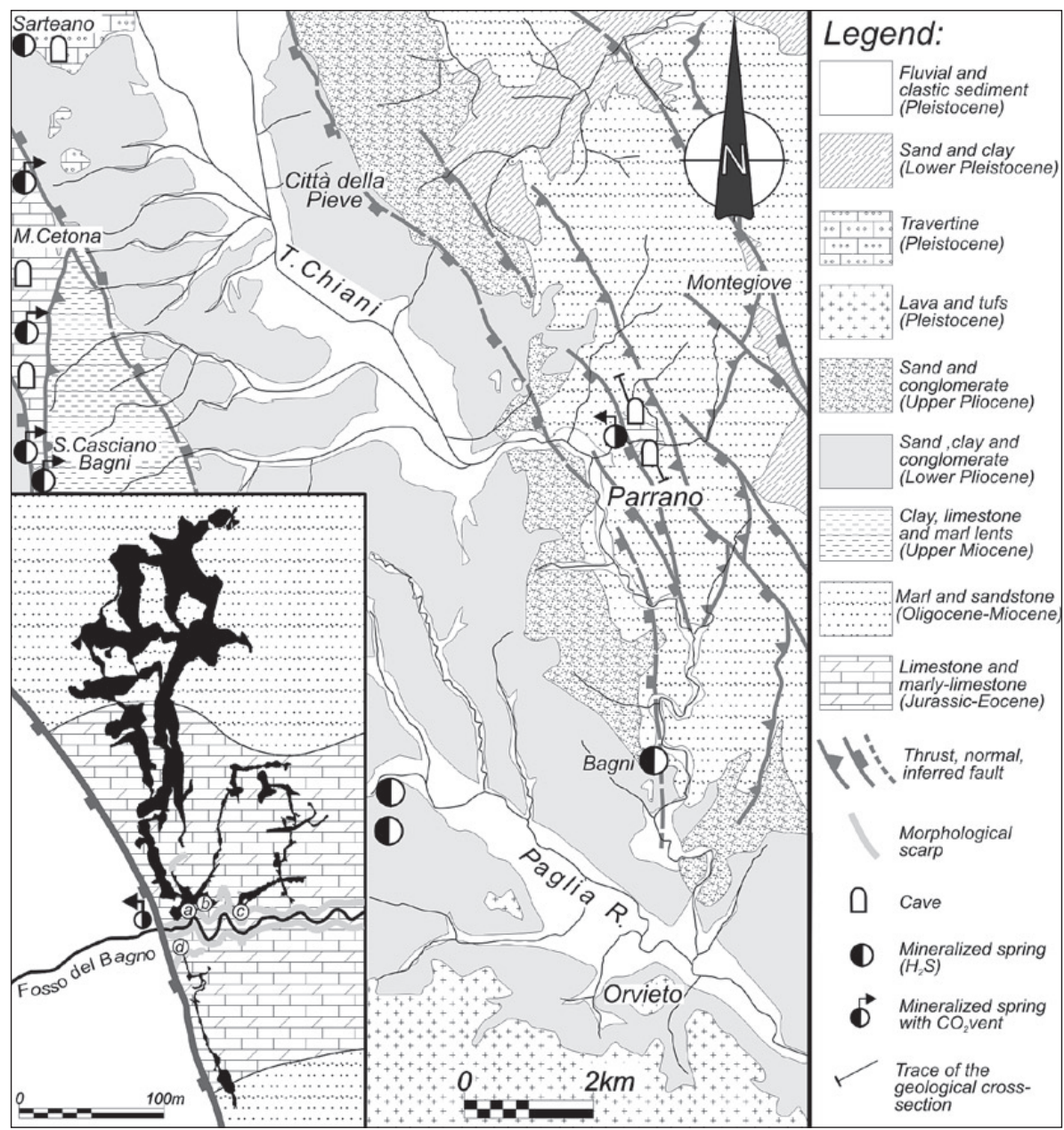

Fig. 11: Geological map of the Parrano area. The insert shows a map of the Fosso del Bagno Gorge with a plan of the main caves. Grotta Grande di Parrano (a); Tana principale inferiore (b); Tana principale superiore (c); Complesso Tane minori (d).

thick, low-permeability marls and a sandstone succession of Oligo-Miocene age (Fig. 11). The Parrano Gorge is within a small NE verging anticline, delimited by a Miocene thrust fault. The SW limb of the anticline is downthrown by a system of Plio-Pleistocene normal faults with an offset of $100 \mathrm{~m}$. Several fracture systems are associated with the faults. Along the southernmost fault scarp, in the north bank of Fosso del Bagno there is a spring with an average discharge of $15 \mathrm{l} / \mathrm{sec}$ and a temperature of $26^{\circ} \mathrm{C}$. The spring is characterized by TDS (Total Dissolved Solids) of up to $1700 \mathrm{mg} / \mathrm{kg}, \mathrm{pH}$ $<6.5, p \mathrm{CO}_{2}$ of $10^{-1} \mathrm{~atm}, \mathrm{H}_{2} \mathrm{~S}$ content of $10 \mathrm{mg} / \mathrm{l}$, and $\mathrm{Ca}-$ $\mathrm{Na}$ and $\mathrm{Cl}-\mathrm{HCO}_{3}$ composition (Fig. 9) (Minissale et al. 2000; Italiano et al. 2004).

Other important mineralized springs and gas vents are located throughout the area, especially at the boundary between limestone and terrigenous sediments (Fig. 11). In Sarteano, large travertine deposits are associated with $\mathrm{CO}_{2}$-rich springs with temperatures of $24^{\circ} \mathrm{C}$. In the outcrops of these travertine deposits, several small caves with prehistoric settlements are located. At S. Casciano dei Bagni, a few springs have temperatures higher than $40{ }^{\circ} \mathrm{C}$ with a gas phase of $6 \%$ $\mathrm{CO}_{2}$ (Minissale et al. 2000; Piscopo et al. 2009). A few kilometers to the south there is an important, medium enthalpy geothermal field of Torre Alfina with many superficial gas vents. Here, the impermeable turbidite sandstone and marl cap rocks seal a $400 \mathrm{~m}$ thick carbonate reservoir, with $\mathrm{pCO}_{2}$ of $4 \mathrm{MPa}$ and temperatures of $140-150^{\circ} \mathrm{C}$ (Barelli et al. 1978). The high $p \mathrm{CO}_{2}$ in the groundwater results from the degassing of deep, pressurized reservoirs as well as the mixing of shallow, cold $\mathrm{Ca}-\mathrm{HCO}_{3}$ groundwater with deep, thermal saline $\mathrm{Ca}-\mathrm{SO}_{4}\left(\mathrm{HCO}_{3}\right)$ groundwaters.

\section{CAVES}

The Parrano gorge underground karst system consists of at least eight solution caves developed at different altitudes in both sides of a small, deep gorge containing a stream carrying seasonal runoffs. The caves are locally known as Tane del Diavolo (Devil's Holes) and represent an important Neolithic archaeological site, known since the beginning of the last century (Lippi Bomcambi 1938). 


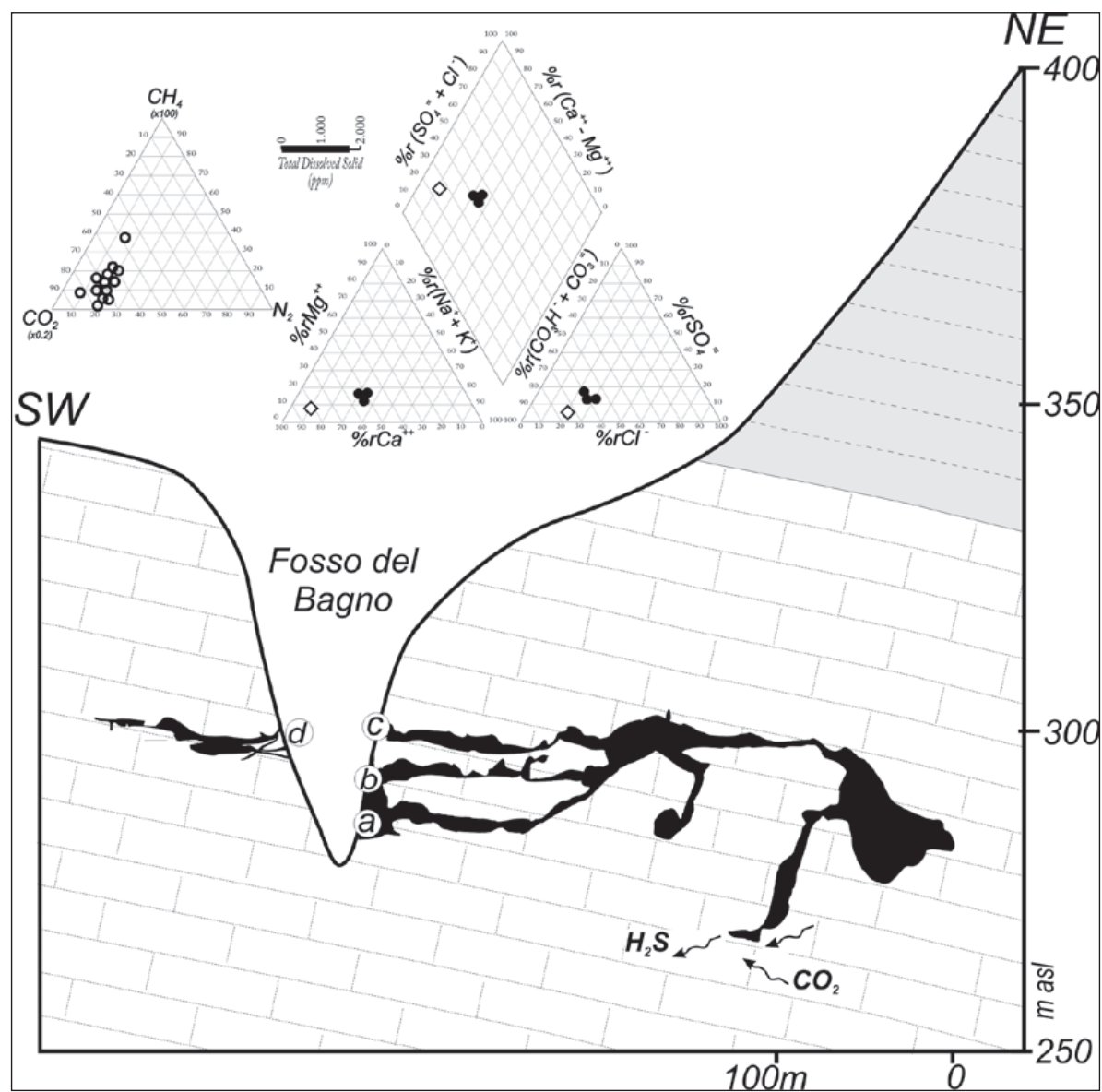

Fig. 12: Geological cross-section through the Fosso del Bagno indicating the caves. Brick pattern represents the Upper Cretaceous cherty limestone and the grey, Paleocene marls. The cross-section trace is in Fig. 11. Note that horizontal and vertical scales are different. In the upper part, the Piper diagram shows the compositions of the principal ions and gases of the Bagno spring water (from Italiano et al. 2004).
The Grotta Grande di Parrano, located in the northern bank of the gorge a few meters from the stream, is about $600 \mathrm{~m}$ long (Figs. 11 \& 12). The solution ramiform passages consist of a main gallery (several meters wide) that ascends to a large room where a network of anastomotic passages and pits extend to a maximum depth of 50 meters. The cross-section of the passages is subcircular with cupola and blind shaft morphologies as well as protruding chert balls and discs formed by differential solution (Fig. 13). Carbonate speleothems are common in the upper levels. In the lower branch, a $30 \mathrm{~m}$ deep, subcircular shaft extends to a small room where a sulfuric stream flows. In the proximity of the sulfuric stream, the air moisture is rich in $\mathrm{H}_{2} \mathrm{~S}$ and $\mathrm{CO}_{2}$ released from the groundwater that act as the main promoters of limestone corrosion in the cave walls (Menichetti et al. 2008). The thermal water heats the air in the cave to $25^{\circ} \mathrm{C}$, and the $\mathrm{CO}_{2}$ concentration is $0.02 \%$. The process of limestone corrosion manifests as small white spots on the limestone of about one $\mathrm{cm}$ in diameter, where gypsum replaces the calcium carbonate. This microcrystalline gypsum is often mash and can easily fall off. Alternatively replacement gypsum crust can contain centimeter-sized recrystallized selenite crystals formed as a result of the dissolution of preexisting gypsum. Spongework, corrosional limestone pockets and cupola ceilings are common morphologies. Alteration crusts within yellow clay deposits as well as recrystallized gypsum rosettes are present in different rooms of the cave.

The Tana Principale Inferiore opens with a large entrance on the gorge bank about 10 meters from the stream. The cave extends for about $200 \mathrm{~m}$ with passages that reach a gallery about ten meters high. The section is developed along a system of N-S fractures from which ramiform passages split off, ending abruptly in narrow fissures (Fig. 13a). The terminal room is characterized by carbonate speleothems dominated by stalactites. The ceilings commonly display cupola morphologies and chert protrusions (Fig. 13b). Brown and yellow clay sediments cover the pavements, and gypsum microcrystals are observable in several passages.

The Tana Principale Superiore is located about $30 \mathrm{~m}$ above the stream and developed as a single passage of about $150 \mathrm{~m}$ in length (Figs. $11 \& 12$ ). The fossil passages consist of subcircular galleries of metric size, present morphologies that are primarily controlled by stratigraphy and a system of N-S fractures that end abruptly in narrow galleries. 


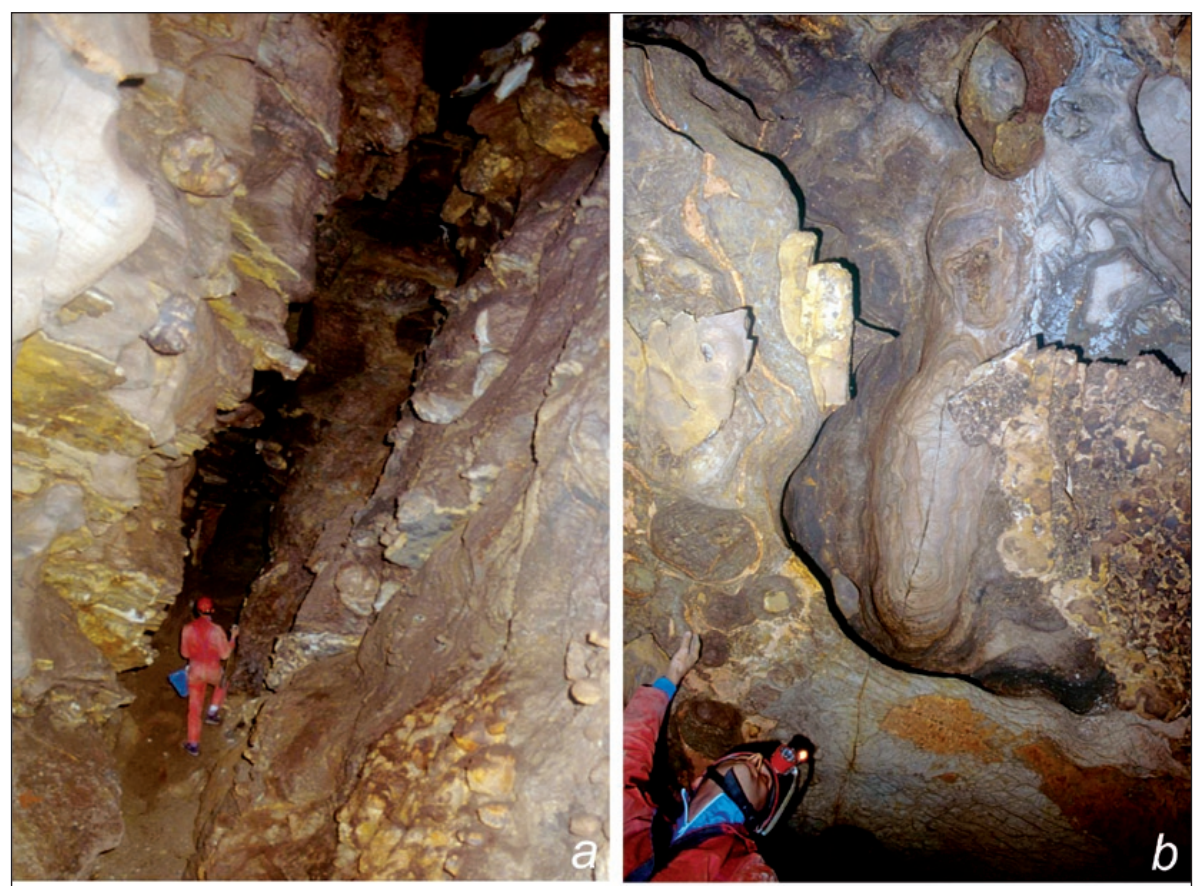

Fig. 13: Parrano caves - a) fissure gallery with chert protrusions in the walls; b) cupola ceiling morphologies; c) phreatic passages with pendants; d) vertical conduits with clay deposits.
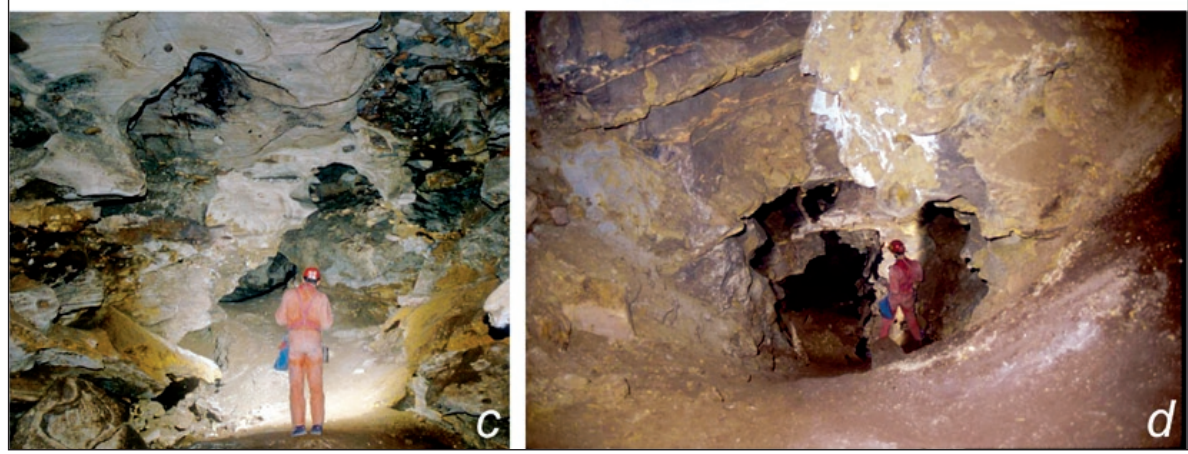

In the southern bank of the gorge at an altitude of about $300 \mathrm{~m}$ is the entrance to the Complesso della Tane minori (Figs. $11 \& 12$ ). This solution cave is a single ascending elongated passage, metric in size, that extends to a large room $130 \mathrm{~m}$ from the cave entrance. Other small caves open on both sides of the gorge; a few are solution passages and many others are scattered blind fissures. All the karst systems of the Parrano gorge present morphologies, speleothems and cave deposits similar to those found in the active hypogenic system of the Umbria Marche Apennines of Frasassi and Acquasanta Terme (Galdenzi \& Menichetti 1995).
Underground karst evolution can be linked to the ascending $\mathrm{CO}_{2}$ and $\mathrm{H}_{2} \mathrm{~S}$-rich waters as the regional water table falls. The gorge morphology and the cave entrance locations suggest that the stream has cut through the preexisting underground karst system. The ages of the different stages of the karst evolution are poorly constrained, but they can be placed within the framework of the Quaternary morphologic evolution of the area, during which volcanic activity played an important role.

\section{DISCUSSION AND CONCLUSION}

Despite the fact that the western Umbria caves have developed in different geological and hydrogeological con- texts, most show patterns and morphologies that can be linked to a hypogenic origin. The karst in the region is 
not homogeneously distributed, and a relationship between the cave development and the regional geomorphic events is not well established. A more dynamic view of cave pattern development and evolution in space and time will take into account the general elevation variations of the regional water table together with episodic gas emissions.

The caves are characterized by both fossil and active passages in which thermal water rich in $\mathrm{H}_{2} \mathrm{~S}$ as well as endogenic $\mathrm{CO}_{2}$ plays a determinant role in speleogenesis. These hypogenic processes can be linked to the oxidation of the $\mathrm{H}_{2} \mathrm{~S}$ to sulfuric acid by oxygen-rich groundwaters. The cave morphologies suggest that the oxidation zone of $\mathrm{H}_{2} \mathrm{~S}$ is not restricted to the shallow groundwater levels but can be extended to deeper sections of the aquifer to which input of fresh water via a complex regional hydrogeological circuit could occur.

In western Umbria, there are several low-temperature $\mathrm{CO}_{2}$ gas emissions with flow rates estimated at $10^{11} \mathrm{~mol} \mathrm{yr}^{-1}$ (Rogie et al. 2000) in close proximity to the main outcrops of travertine deposits (Fig. 1). In the region, the origin of the gases is still debated since both $\mathrm{CO}_{2}$ and $\mathrm{H}_{2} \mathrm{~S}$ are often associated with $\mathrm{CH}_{4}$ and $\mathrm{He}$ (Minissale 2004). The origin of the non-volcanic $\mathrm{CO}_{2}$ appears to be mantle degassing and the subsequent thermogenic reactions of carbonates. The $\mathrm{H}_{2} \mathrm{~S}$ is a product of gas reactions and re-equilibration in rock/mineral buffered geothermal systems in the buried Triassic anhydrites (Minissale et al. 2000).

The $\mathrm{pCO}_{2}$ values of the groundwaters in Central Italy range from 0.03 to $0.1 \mathrm{~atm}$, increasing the solubility of $\mathrm{CaCO}_{3}$ by an order of magnitude with respect to the normal karstic waters. The breakthrough mechanism of progressive fracture widening by epigenic $\mathrm{CO}_{2}$ corrosion is here modified to a homogeneous widening of the fracture walls along their complete length by the rising of endogenic $\mathrm{CO}_{2}$. An increase in $\mathrm{pCO}_{2}$ of 0.002 atm from a continuous volcanic input is sufficient to reduce the breakthrough time for a fracture aperture by about half (Gabrovšek et al. 2000). Additionally, there is a positive feedback between $\mathrm{H}_{2} \mathrm{~S}$ oxidation and the release of $\mathrm{CO}_{2}$ in the shallower groundwaters providing supplementary aggressiveness towards the carbonate dissolution (Palmer \& Palmer 2000).

The travertine deposits represent the other end member of these karst processes. They form as a result of degassing of surfacing carbon dioxide-rich groundwaters containing $>2 \mathrm{mmol} \mathrm{l}^{-1}$ calcium (Pentecost 2005). In order for this to occur, the dissolution of previously deep-seated carbonate rocks by corrosive, $\mathrm{CO}_{2}$-rich groundwater is necessary. The origin and evolution of a cave, such as Pozzi della Piana within a travertine deposit where $\mathrm{H}_{2} \mathrm{~S}$ action has been linked to gypsum deposits, leaves open several questions related to the timing of the speleogenesis.

Several caves have developed in cherty and marly limestone normally considered non-karstic rocks. These lithologies have a $\mathrm{CaCO}_{3}$ content of 60 to $80 \%$, with the remaining composition represented by clay minerals, mainly illite and montmorillonite (Johnsson \& Reynolds 1986). The corrosive $\mathrm{H}_{2} \mathrm{~S} / \mathrm{CO}_{2}$ gases, both in vadose and in phreatic zones, react with the carbonate rocks as well as alter the insoluble residues producing various speleogenetic products. The presence of carbonate cement in the marly rock fabrics accelerates the rock weathering process. Furthermore, the abundant microbial communities associated with active caves today need to be taken into consideration (Sarbu et al. 2001; Engel et al. 2004).

The complex chemical reactions between the different minerals in contact with carbonate rocks, the presence of significant concentrations of $\mathrm{Cl}$ and $\mathrm{Na}$ in several karstic groundwaters as well as the reactions at the gas/water interface and the role played by organic matter all require more detailed study. Moreover, the cooling of thermal water during its ascent along conduits increases the $\mathrm{CO}_{2}$ aggressiveness, thus corrosion acting almost uniformly along the surfaces, producing a dramatic increase in the hydrologic flow and karst void development (Andre \& Rajaram 2005).

The key to understanding the unusual nature of the cave patterns in Central Italy is to take into account the geology, hydrogeology and water and gas chemistry that control the hypogenic speleogenesis.

\section{ACKNOWLEDGEMENTS}

I greatly benefitted from discussion on western Umbria cave origin with Francesco Salvatori and Stefano Tosti. I appreciate the cooperation of the speleologists of the Centro Escursionistico Naturalistico Speleologico of
Costacciaro (CENS) for help in the cave surveys. Furthermore I acknowledge the valuable review comments and suggestions from the editor Jo De Waele and the reviewers Louise Hose and Kevin Stafford. 


\section{REFERENCES}

Andre, B.J. \& H. Rajaram, 2005: Dissolution of limestone fractures by cooling waters: early development of hypogene karst systems.- Water Resour. Res., 41, w01015, doi 10.1029/2004WR03331.

Barelli, A., Celati, R. \& G. Manetti, 1978: Gas-water interface rise during early exploitation tests in Alfina geothermal field northern Latium, Italy.- Geothermics 6, 199-208.

Boni, C., Bono, P. \& G. Capelli, 1988: Schema idrogeologico dell'Italia Centrale.- Mem. Soc. Geol. It., 25, 991-1012.

Brozzetti, F., 1995: Stile strutturale della tettonica distensiva nell'Umbria Occidentale: l'esempio dei massicci Mesozoici Perugini.- Studi Geologici Camerti, Special Volume, 1, 105-119.

Cavazza, W. \& F.C. Wezel (eds.), 2003: Geology of Italy.Episodes, 26, 3, 268.

Chiodini, G., Giaquinto S. \& A.R. Zanzari, 1982: Caratteri idrochimici e analisi della distribuzione degli indicatori geotermici nelle acque del bacino del Fiume Paglia.- C.N.R. P.F.E. R.F., 16, 56-90, Roma.

Chiodini, G., Frondini, F., Kerrick, D.M., Rogie, J., Parello, F., Peruzzi L. \& A. R. Zanzari, 1999: Quantification of deep $\mathrm{CO}_{2}$ fluxes from Central Italy. Examples of carbon balance for regional aquifer and of soil diffuse degassing.- Chemical Geology, 159, 222.

Compagnoni, B., Valletta, M., Martelli, G., Nappi, G. \& G. Pialli, 1981: Carta Geologica dell'Umbria 1:250.000. Servizio Geologico d'Italia 1. Sheet, Roma.

Conti, A., Sacchi, E., Chiarle, M., Martinelli, G. \& G.M. Zuppi, 2000: Geochemistry of the formation waters in the Po plain (Northern Italy): on overview.- Applied Geochemistry, 15, 51-65.

Della Vedova, B., Bellani, S. \& P. Squarci, 2001: Deep temperature surface heat flow distribution.- In: G. Vai \& P. Martini (eds.) Anatomy of an Orogen: the Apennines and Adjacent Mediterranean Basins. Kluwer, pp. 65-76, Dordrecht, The Netherlands.

Dessau, G., 1956: Contributo alla geologia del gruppo del Monte Tezio (Perugia).- Boll. Soc. Geol. It., 75, 2, 20-54.

DuChene, H.R., Hill, C.A., Hose, L.D. \& J.A. Pisarowicz (eds.), 2000: The caves of the Guadalupe Mountains research symposium.- Journal of Cave and Karst Studies, 62, 2, 1-159.

Engel, A.S., Stern, L. A. \& P.C. Bennet, 2004: Microbial contributions to cave formation: new insights into sulfur acid speleogenesis.- Geology, 32, 5, 369-372.
Erol, O., 1993: Travertine formations in the Antalya area as correlated sediments of karstic erosional phases in the surrounding Taurus Mountains.- In: Gunay, G., Johnson, I.A. \& W. Back (eds.) Hydrogeological Processes in Karst Terranes, International Association of Hydrological Sciences, pp. 53-64 Wallingford, UK.

Gabrovšek, F., Menne, B. \& W. Dreybrodt, 2000: A model of early evolution of karst conduits affected by subterranean $\mathrm{CO}_{2}$ sources.- Environmental Geology, 39, 531-543.

Galdenzi, S. \& M. Menichetti, 1989: Evolution of underground karst systems in the Umbria-Marche Appennines in Central Italy.- In: Hazslinszky, T. \& B.K. Takacsne (eds.) Proceedings, International Congress of Speleology, 10 th August 1989 Budapest, vol.3, 745-747, Budapest Hungary.

Galdenzi, S. \& M. Menichetti, 1995: Occurrence of hypogenic caves in a karst region: examples from central Italy.- Environmental Geology, 26, 39-47.

Galdenzi, S., 2009: Hypogene caves in the Apennines (Italy).- In Klimchouk A. (ed.) Hypogene Speleogenesis and Karst Hydrogeology of Artesian Basins. Ukrainian Institute of Speleology and Karstology. S.P.1, pp. 101-115 Simferopol, Ukraine.

Hill, C.A., 1987: Geology of Carlsbad Cavern and other caves in the Guadalupe Mountains, New Mexico and Texas.- New Mexico Bureau of Mines and Mineral Resources, Bulletin, 117, 150.

Italiano, F., Martinelli, G. \& A. Rizzo, 2004: Seismogenic-induced variations in the dissolved gases of the thermal waters of the Umbria region Central Apennines, Italy during and after the 1997-1998 seismic swarm.- G-Cubed 5, 11, doi:10.1029/ 2004GC000720.

Johnsson, M.J. \& R.C. Reynolds, 1986: Clay mineralogy of shale-limestone rhythmites in the Scaglia rossa (Turonian-Eocene), Italian Apennines.- Journ. of Sed. Res., 56, 4, 501-509.

Klimchouk, A., 2007: Hypogene speleogenesis: hydrogeological and morphogenetic perspective.- Nat. Cave and Karst Research Institute, Carlsbad N.M. USA, SP.1, 106.

Laurenzi, M.A, Villa, I. \& F. Stoppa, 1994: Eventi ignei monogenici e depositi piroclastici nel Distretto Ultra-alcalino Umbro-laziale (ULUD): revisione, aggiornamento e comparazione dei dati cronologici.Plinius, 12, 61-65.

Lippi Boncambi, C., 1938: Le Grotte di Parrano.- Le Grotte d'Italia, 2, 3, 13-27. 
Lippi Boncambi, C., 1941: La "Buca del Serpente" presso Ascagnano Perugia.- Boll. Reg. Soc. Geografica Ital., $5,7,642-644$.

Mayer, L., Menichetti, M., Nesci, O., \& D. Savelli, 2003: Morphotectonic approach to the drainage analysis in the North Marche region, central Italy.- Quaternary Intern., 101-102, 157-167.

Menichetti, M., 1987: Analisi spazio-temporale del sistema carsico del M. Cucco.- Atti XV Cong. Naz. Spel. Castellana Grotte, Bari, 731-762.

Menichetti, M., 2003: Gessi d'Italia: Umbria.- Mem. Ist. Ital. Spel., II, 14, 203-208.

Menichetti, M., 2008: Assetto strutturale del sistema geotermico di Acquasanta Terme (Ascoli Piceno).Rend. Soc. Geol. It., 1, 118-122.

Menichetti M., Chirenco, M.I., Onac, B. \& S. Bottrell, 2008: Depositi di gesso nelle grotte del M.Cucco e della Gola di Frasassi, Considerazioni sulla speleogenesi.- Mem. Ist. Ital. Speleol., II, 21, 308-325.

Menichetti, M., 2009: Speleogenesis of the hypogenic caves in Central Italy.- In: White, W.B. (ed.) Proceedings of the $15^{\text {th }}$ Int. Cong.of Speleology, August 2009 Kerrville, 909-915, Kerrville, U.S.A.

Minelli, G. \& M. Menichetti, 1990: Tectonic evolution of the Perugia Massifs area (central Italy).- Boll. Soc. Geol. Ital., 109, 445-453.

Minissale, A., Magro, G., Martinelli, G., Vaselli, O. \& F.Tassi, 2000: Fluid geochemical transect in the Northern Apennines (central-northern Italy): fluid genesis and migration and tectonic implications.Tectonophysics, 319, 199-222.

Minissale, A., Kerrich, D., Magro, G., Murrell, M., Paladini, T., Rihs, S., Sturchio, N., Tassi F. \& O. Vaselli, 2002: Structural, hydrological, chemical and climatic parameters affecting the precipitation of travertines in the Quaternary along the Tiber valley, north of Rome.- Earth Planet. Sci. Lett., 203, 709-728.

Minissale, A., 2004: Origin, transport and discharge of $\mathrm{CO}_{2}$ in Central Italy.- Earth-Science Reviews, 66, 89-141.

Palmer, A.N., 2007: Cave Geology.- Cave book Ed., pp. 453, Dayton, OH, USA.
Palmer, A.N. \& M.V. Palmer, 2000: Hydrogeochemical interpretation of cave patterns in the Guadalupe Mountains, New Mexico.- Journ. of Cave and Karst Studies, 62, 2, 91-108.

Passeri, L., 1963: Labisso II di Monticelli, 126 U/PG.Atti IX Cong. Naz. Speleol., 77-85, Trieste.

Passeri, L., 1967: Ritrovamenti preistorici pozzi piana (Umbria).- Rivista di Scienze Preistoriche, 25, 1, 47- 61.

Passeri, L., 1973: Canalizzazione sotterranea in regime di fluttuazione freatica nel travertino della Piana (Umbria).- Ras. Spel. Ital., 24, 1-4, 83-97.

Peccerillo, A., 2005: Plio-Quaternary Volcanism in Italy.Springer, pp. 369, Berlin.

Pentecost, A., 2005: Travertine.- Springer, pp. 449, Berlin.

Pentecost, A. \& P. Tortora, 1989: Bagni di Tivoli, Lazio: a modern travertine depositing site and its associated microorganisms.- Boll. Soc. Geol. Ital., 108, 315-324.

Piscopo, D., Gattiglio, M., Sacchi, E. \& E. Destefanis, 2009: Tectonically-related fluid circulation in the San Casciano dei Bagni-Sarteano area (M.Cetona ridge-Southern Tuscany): a coupled structural and geochemical investigation.- Boll. Soc. Geol. It., 128, 2, 575-585.

Rogie, J.D., Kerrick, D.M., Chiodini, G. \& F. Frondini, 2000: Flux measurements of non-volcanic $\mathrm{CO}_{2}$ emission from some vents in central Italy.- J. Geophys. Res., 105, 8435-8445.

Sarbu , S.M., Galdenzi, S., Menichetti, M. \& G. Gentile, 2001: Geology and biology of the Frasassi Caves in Central Italy, an ecological multi-disciplinary study of a hypogenic underground ecosystem. In: Wilkens, H. et al. (eds.) Ecosystems of the world. Elsevier, pp. 359-378, New York.

Van Everdingen, R.O., Asif Shakur, M. \& H. Roy Krouse, 1985: Role of Corrosion by $\mathrm{H}_{2} \mathrm{SO}_{4}$ fallout in cave development in a travertine deposit - evidence from sulphur and oxygen isotopes.- Chem. Geol., 49, 205-211.

Viviani, G.C. \& L. Passeri, 1965: Alcune cavità della Valle del Nese.- Rass. Speleol. Italiana, 17, 1-4. 